Clinical data

\begin{tabular}{|c|c|c|c|c|c|}
\hline $\begin{array}{l}\text { Patient } \\
\text { No }\end{array}$ & Age/sex & $\begin{array}{l}\text { Duration of EMS* } \\
\text { before cyclosporin } A \\
\text { use (months) }\end{array}$ & $\begin{array}{l}\text { Duration of } \\
\text { cyclosporin } A \\
\text { use (months) }\end{array}$ & $\begin{array}{l}\text { Significant side effects } \\
\text { of cyclosporin } A\end{array}$ & $\begin{array}{l}\text { Reason for } \\
\text { discontinuing } \\
\text { cyclosporin } A\end{array}$ \\
\hline $\begin{array}{l}1 \\
2\end{array}$ & $\begin{array}{l}44 / F \\
61 / F\end{array}$ & $\begin{array}{l}13 \\
20\end{array}$ & $\begin{array}{l}3 \\
4\end{array}$ & $\begin{array}{l}\text { 'Stiffness' } \\
\text { Abdominal pain, } \\
\text { diarrhoea }\end{array}$ & $\begin{array}{l}\text { Patient's request } \\
\text { Patient's request }\end{array}$ \\
\hline 3 & $35 / F$ & 7 & 19 & $\begin{array}{l}\text { Renal insufficiency, } \\
\text { hypertension, } \\
\text { hirsutism }\end{array}$ & Renal insufficiency \\
\hline 4 & $41 / F$ & 11 & 8 & $\begin{array}{l}\text { Renal insufficiency, } \\
\text { hypertension }\end{array}$ & Renal insufficiency \\
\hline $\begin{array}{l}5 \\
6\end{array}$ & $\begin{array}{l}56 / \mathrm{F} \\
33 / \mathrm{M}\end{array}$ & $\begin{array}{r}15 \\
6\end{array}$ & $\begin{array}{r}8 \\
16\end{array}$ & $\begin{array}{l}\text { Renal insufficiency, } \\
\text { rhabdomyolysis, } \\
\text { hypertension }\end{array}$ & $\begin{array}{l}\text { Lack of efficacy } \\
\text { Renal insufficiency }\end{array}$ \\
\hline $\begin{array}{l}7 \\
8\end{array}$ & $\begin{array}{l}38 / \mathbf{F} \\
52 / \mathbf{F}\end{array}$ & $\begin{array}{l}18 \\
12\end{array}$ & $\begin{array}{l}6 \\
1\end{array}$ & Worsening myalgias & $\begin{array}{l}\text { Lack of efficacy } \\
\text { Myalgias }\end{array}$ \\
\hline
\end{tabular}

${ }^{*}$ EMS = eosinophilia myalgia syndrome.

were included in this study; this group might have derived a substantial benefit from corticosteroid treatment that cyclosporin A would do little to augment. Alternatively, the manifestations unresponsive to cyclosporin A might have been either irreversible or too slow to reverse to be detected in a small, short term trial.

Our data show limited usefulnesss of cyclosporin when used relatively early in this disease. Given what is now known about EMS, one would expect that the efficacy of any regimen aimed at reduction of inflammation would diminish further as the syndrome progressed, and that any advances in treatment are unlikely to be found among the immunomodulatory drugs.

$$
\begin{array}{r}
\text { DANIEL J CLAUW } \\
\text { JEFF A ALLOWAY } \\
\text { PAUL KATZ } \\
\text { Division of Rheumatology, Immunology and Allergy } \\
\text { Department of Medicine } \\
\text { Georgetown University Medical Center } \\
3800 \text { Reservoir Road NW } \\
\text { Washington DC 200007-2197 } \\
\text { USA }
\end{array}
$$

1 Swygert L A, Maes E F, Sewell L E, et al Eosinophilia myalgia syndrome: results of national surveillance. FAMA 1990; 264: 1698-703.

2 Read C A, Clauw D J, Weir C, DaSilva A T, Katz P. Dyspnea and pulmonary function in the L-tryptophan induced eosinophilia myalgia the L-tryptophan induced eosinophilia mya syndrome (EMS). Chest 1992; 101: 1282-6.

3 James T N, Kamb M L, Sandberg G A, Silver R M, Kilbourne E M. Postmortem studies of the heart in three fatal cases of the eosinophiliamyalgia syndrome. Ann Intern Med 1991; 115 102-10.

4 Smith B E, Dyck P J. Peripheral neuropathy in the eosinophilia-myalgia syndrome associated with L-tryptophan ingestion. Neurology 1990; 40: $1035-40$.

5 Belongia E A, Hedberg C W, Gleich G J, et al. An investigation of the cause of the eosinoAn investigation of the cause of the eosino-
philia-myalgia syndrome associated with philia-myalgia syndrome associated with
tryptophan use. $N$ Engl f Med 1990; 323: tryptoph

6 Toyooka T, Yamazaki T, Tanimoto T, et al. Characterization of contaminants in EMS-associated L-tryptophan samples by high performance liquid chromatography. Chem Pharm Bull (Tokyo) 1991; 39: 820-2.

\section{Postural variation in von Willebrand factor antigen}

Sir: von Willebrand factor antigen (vWFAg) is the antigenic component of von Willebrand factor and is synthesised by endothelial cells and megakaryocytes. Raised concentrations of vWFAg have been reported in a variety of connective tissue diseases, including vasculitis systemic lupus erythematosus, and systemic sclerosis.' Although it is an acute phase reactant, ${ }^{2}$ raised levels in some of these diseases may reflect damage to the endothelial cell. ${ }^{3}$ As most inpatients lie quietly on a bed, and most outpatients are subject to movement during their clinic visits we sought to determine whether differences in vWFAg between these groups might be due to posture and activity.

We tested the effect of different postures on circulating levels of $\mathrm{VWFAg}$ in healthy hospital and laboratory staff. In the first study blood was taken into an EDTA tube from a group of five men and five women (mean age 29 (SD 5) years) immediately after normal kinetic laboratory activity. After resting quietly in the sitting position for 15 minutes, blood was taken from the opposite arm. Plasma was obtained after centrifugation at $\mathbf{3 0 0 0} \mathrm{rpm}$ for 10 minutes and vWFAg estimated by enzyme linked immunosorbent assay (ELISA). ${ }^{4}$ Mean (SD) concentrations of $\mathbf{v W F A g}$ immediately after activity were $1160 \mathrm{IU} / \mathrm{l}$, (150), but after the rest period they had fallen to 1040 (220) $(p<0.05)$, Wilcoxon rank sum test applied).

In a separate study six men and five women (aged 22-38) were rested lying down, face up, for 25 minutes, after which blood was taken. They then sat upright in a chair for a further 25 minutes and blood was taken a second time. After 25 minutes lying down plasma vWFAg concentrations were 950 (270) IU/l, but after 25 minutes sitting up levels increased to $1070(200)$ IU $/ 1(p<0.05)$.

This small study identified changes in vWFAg concentrations depending upon variations in posture and activity. As vWFAg has been shown to rise after exercise ${ }^{5}$ this finding is not surprising. It points, however, to a possible artefact in vWFAg determination in patients. This may become important in the case of patients with, for example, rheumatoid arthritis, who are often admitted to hospital for bed rest. Reductions in vWFAg in these patients may reflect their posture and not necessarily reduced activation/injury of the endothelium. To avoid the possible problem in outpatient clinics we suggest that patients rest sitting for a minimum of 15 minutes before venepuncture.

A BLANN M I V JAYSON Rheumatic Diseases Centre University of Manchester Hope Hospital United Kingdom

M H POPE

A M KAIGLE

D WILDER Orthopaedic and Rehabilitation University of Vermon
Burlington VT05404, USA

J N WEINSTEIN University of Iowe Hospitals and Clinics

Correspondence to: Professor Jayson.
1 Belch J F F, Zoma A, Richards I M, McLaughlin $K$, Forbes C D, Sturrock R D. Vascula damage and factor VIII related antigen in the rheumatic diseases. Rheumatol Int 1987; 7 : 107-11.

2 Pottinger B E, Read R C, Paleolog E M, Higgins $P$ G, Pearson J D. von Willebrand factor is an acute phase reactant in man. Thromb Res 1989; 53: 387-94.

3 Kahaleh M B. The role of vascular endothelium in the pathogenesis of connective tissue disease endothelial injury, activation, participation and response. Clin Exp Rheumatol 1990; 8: 595-601

4 Short P E, Williams I C E, Picken A M, Hil F H G. Factor VIII related antigen: an improved immunoassay. Med Lab Sci 1982, 39: 351-5.

5 Prowse C V, Farrugia A, Boulton F E, et al. A comparative study using immunological and biological assays of the haemostatic responses to DDAVP infusion, venous occlusion and to DDAVP infusion, venous occlusion and 51: $110-4$.

\section{Hypertrophic osteo- arthropathy and AIDS}

Sir: Rheumatic manifestations of human immunodeficiency virus (HIV) are diverse. Some conditions appear to be unique to HIV infected patients, whereas others, such as Reiter's syndrome, may be more widespread. Reports of patients with coexistent acquired immune deficiency syndrome (AIDS) and diseases of unknown cause are often interesting as they may help to clarify their pathogenesis. One of these syndromes is hypertrophic osteoarthropathy, an entity occasionally associated with chronic bacterial infections and other conditions, especially bronchogenic carcinoma Despite the high prevalence of opportunistic infections in patients with AIDS, associated hypertrophic osteoarthropathy has rarely been reported. We present a patient with AIDS who developed severe rapidly progressive hypertrophic osteoarthropathy concurrently with anaerobic necrotising pneumonitis.

A 29 year old man, an intravenous drug and alcohol abuser, known to be HIV positive, was admitted owing to development of severe pain and oedema in his arms and legs two months previously. He also complained of a persistent cough, with foul smelling sputum, occasionally haemoptoic, fever, and pleuritic chest pain. He had lost $10 \mathrm{~kg}$ of weight.

On admission, the patient appeared cachectic, was unable to walk, and had a temperature of $38.5^{\circ} \mathrm{C}$. His mouth showed oropharyngeal candidiasis. Inspiratory rates were heard in the superior field of the right hemithorax. Heart sounds were normal, except for rhythmic tachycardia. The liver was felt $5 \mathrm{~cm}$ under the costal margin. There was no splenomegaly and diseased lymph nodes were not palpable. Both forearms, hands, legs, and feet showed prominent oedema, local warmth, perspiration, and tenderness to pressure. Osteoarticular examination disclosed prominent clubbing of the fingers and toes, as well as synovitis, with moderate effusion of the knees, ankles, elbows, wrists, and proximal interphalangeal joints of the hands.

Blood studies showed haemoglobin $90 \mathrm{~g} / \mathrm{l}$, leucocytes $7.3 \times 10^{9} / 1$ (lymphocytes $1.965 \times$ $10^{9} / 1 \mathrm{CD} 4+0.55 \times 10^{9} / 1, \mathrm{CD} 4+/ \mathrm{CD} 8+$ ratio 0.5 ), platelets $367 \times 10^{9} / 1$, erythrocyte sedimentation rate $105 \mathrm{~mm} / \mathrm{h}$. Serum alkaline phosphatase was $425 \mathrm{U} / \mathrm{l}$ (normal <279). Results of other routine tests were normal, including calcium, phosphorus, creatinine, glucose, aspartate transaminase, alanine transaminase, and lactate dehydrogenase. Urine analysis results were also normal. 